\title{
Gaming (In)formation
}

\section{Gamified, Transformational Learning in \\ Research and Theology}

Chris Rosser, Oklahoma Christian University

\begin{abstract}
Gamification refers to the application of game design principles to non-game contexts, infusing education with curiosity, imagination, and play. Moreover, gameful design enables instructors to reimagine courses that incorporate basic game architecture, story, and aesthetic. Below, theological librarian Chris Rosser demonstrates examples of gamified instruction within curricular and co-curricular contexts. First, Chris describes a research-oriented course that normalizes experience of the Bible as "strange" by framing students' journey through texts around the "Hero's Journey" construct. Second, he discusses a co-curricular escape roomstyle online module that teaches and assesses information literacy outcomes as students escape from a virtual library. Gameful design in research instruction and theological education opens new horizons for actualizing (in)formation as librarians-as-teachers form and inform those we serve. Readers will be well served by viewing three associated videos: Concept (bit.ly/gamifiedconcept); Curricular (bit. ly/gamifiedcurricular); Co-curricular (bit.ly/gamifiedco-curricular). The videos and adapted slides (bit.ly/gamifiedcontent) greatly enhance comprehensibility of what follows.
\end{abstract}

\section{MOVE 1: ADVENTURERS' MAP}

Greeting. Good afternoon, I'd like to thank each of you for joining this session entitled "Gaming (In)formation: Gamified, Transformational Learning in Research and Theology.” My name is Chris Rosser and I serve as theological librarian for the Beam Library at Oklahoma Christian University.

Let me begin with a question, see what you think: Would you rather we start today's conversation with a banal, "Hello, friends, today we're going to talk about gamification in research instruction and theological education"? Or would you find it more compelling if I began like this-"Hello, friends, adventurers, welcome to the 
Quill and Arrow, a virtual waystation where wayfarers gather, and though I can see only your pixelated selves, I discern that we are all children of blood and bone, all instruments of vengeance and virtue." Or, what if I began with, "If you are a dreamer come in ..."?

Certainly, some of you may find slight appropriation of Tomi Adeyemi's Children of Blood and Bone or quick allusion to Shel Silverstein's Where the Sidewalk Ends off-putting-let's please dispense with the kitsch and get down to the nitty gritty. But some of you-you dreamers, wishers, liars, hopers, prayers, magic bean buyers ... you pretenders-you find something within stirred to life by invitation to follow the sidewalk to the place where learning and imagination intersect, perchance there to make a devil's bargain at the crossroads.

Well, I want to invite you to play a game with me as we move through this presentation. As we move along, you'll hear me offhandedly reference four monsters-the first letter of the name of each of these four monsters spells a word, and that word is key! Listen for the monster names, use the first letter of each name to discover our keyword, and escape this presentation unscathed! If you don't find our keyword, alas, game over, you'll end up in the place where recorded presentations go to die, rewatching and rewatching, torturously searching for the key, and who can be bothered with that? OK, friends, adventurers-let's play, let's begin.

First, we need to take a look at our map. Oh, the places we'll go on this under-thirty-minute journey together! We'll begin by kitting up here at the Quill and Arrow-we'll gain some conceptual and pedagogical framework for thinking about gamification in education. Then, we'll begin our hero's journey into a strange, new world by considering gamification in curricular spaces through looking at an example of a gamified course that invites students to inhabit story as the medium for learning. After that, we'll think about gamification in co-curricular spaces as we visit a dojo of strange effects to sharpen skills and develop new competencies. And, finally, we'll return here, to the Quill and Arrow, to contemplate experience, count treasure, and for a five-minute Q\&A—but alas, friends, it's BYOFA, bring your own flagons of ale.

\section{MOVE 2: KITTING UP}

We begin here at the Quill and Arrow, prepping for our journey primarily by gaining a grammar of the gamification of education. 
Simply put, gamification refers to the application of game-design principles to non-game contexts (Boskic and Hu 2015). Most of us consider information literacy instruction and theological research as non-game contexts, although some of us have attempted to spice up our teaching by incentivizing interaction with Snickers bars, or by turning students loose in the library for a noiseless scavenger hunt, with lurking library aides and a menace of shushing fingers at every tiptoed turn.

Gamifying a learning experience offers a means for imbuing education with curiosity, imagination, and play. It offers freedom to make mistakes (in a game, a mess-up means starting over again and again until you've gained the skills to level up), and gamification incorporates a number of important pedagogical ideas, like intrinsic versus extrinsic motivation, feedback and reward, and success versus resilience in the face of failure (Cohen 2011; Dichev and Dicheva 2017; Kapp 2012; McGonigal 2011). Through gamified learning, students are driven by desire to explore and overcome challenges, as well as by desire for rewards (e.g., points or badges that signify achievement). Students sharpen each other through enhanced collaboration and by playful competition. Students learn to problem-solve through trial and error, viewing failure as instructive rather than punitive. Gamification offers a powerful means for rethinking how we do teaching and learning.

At the same time, gamifying learning "is not a simple process and can be quite complicated to implement correctly. It is not simply a matter of adding common game elements, such as points, badges, and leaderboards, to existing processes or systems. Such a surface approach of gamifying existing systems translates to superficial benefits, if any" (Cheong, Filippou, and Cheong 2014, 233). For this reason, I've latched onto language offered by Kevin Bell, who writes about gamification in Educause Review. Bell has exchanged the term "gamification" for the concept of "gameful design." He says, "The distinction is subtle but important. Whereas gamification equates to making a game of an activity, gameful design looks at the various aspects and intrinsic motivators that are embedded in successful games (and in other nongame events) and asks whether those elements can be replicated and woven into classroom and online activities ... Gameful design thus looks at the elements that make games, or other forms of engagement, intriguing and then applies those principles to educational experiences” (Bell 2018, 42). This 
reframe-from gamification to gameful design—has been a game changer for my own teaching.

Before offering examples of gameful design, I want to describe a philosophy of teaching that undergirds these ideas about instruction, specifically how our identity as librarians-as-teachers-or perhaps teachers-as-librarians (however you see yourself) ... how our identity as librarians and teachers-informs thinking about gamification.

As you know, our students are whole people whose capacity to thrive and to understand, whose desire and imagination, are each shaped by transformative learning experiences both inside and outside our classrooms. And, as you also know, our libraries are co-curricular spaces for learning, which positions librarians-asteachers differently in relation to students from other professors and instructors on our campuses.

On our campuses, we talk a lot about faith and learning. It just so happens that, ideally, the center of learning is also the center of love: love and learning each requires encounter with that which is not self, something different, someone who is other. Encounter with difference is the beating heart of learning and love. So we've come to understand the library as a co-curricular third space, positioned outside the classroom yet integral to classroom learning and student success.

In the Beam Library, where I work, in all we do we continue to conceptualize and emphasize our identity as third space on our campus, intentionally facilitating encounter between self (sameness) and neighbor (difference). In our context, this encounter is communicated by our catchword (in)formation, a simple reminder of who we are and how we serve as we live into our educational and spiritual aims.

Our libraries exist at the intersection of information and formation: we build, maintain, and support our institution's educational substructure; we also facilitate generative, loving, complex conversations in generously hospitable spaces among all neighbors who inhabit our campus, virtually and in person. Our libraries exist as generous spaces for encounter, and formation is essential to the information we provide.

This understanding of the library infuses and electrifies our teaching. Learning is an encounter between self (sameness) and other (difference). Whole-person learning considers body, mind, heart, and soul-aspects captured here as thriving, understanding, desir- 
ing, and imagining. Through facilitated encounters between self and other, students enlarge capacity to thrive, broaden understanding, clarify desire, and electrify imagination, so that love and learning transform body, mind, heart, and spirit. I'm employing STUDIO as an acrostic, because studio calls to mind images of a workshop—scraps of wood litter and spilled paint stains the floor, creation-in-process decorates walls and tabletops, tools all around, a space made buzzy by messy creativity, the perfect space for kitting up before adventure.

Now, you may see yourself as mage or wandering bard, paladin, elf, thief, rogue, or cleric-I want to fully own the identity librarianas-teacher, teacher-as-librarian, and my purpose therefore is (in) formation-to reach and transform a student's heart, soul, mind, and strength. I recognize that the truest path to the heart is not through the head but through the gut, and gamification enables us to bring learning to spaces of desire. Transforming the whole person involves reorienting or clarifying desire so that students' love (i.e., what they desire) vectors more truly toward God and neighbor. Love is therefore both the motivation and goal of teaching.

So I say this to underscore that gamification is not kitsch-we do not diminish ourselves as instructors by incorporating gameful design. Alas, perceptions that one-off info literacy courses or research workshops held in the dank dungeons of the co-curricular library are inferior to the pure light shining from curricular classrooms-such perception of inferiority is the great hydra we must battle (ahem, remember the game we're playing: perception of inferiority is the great hydra we must battle, and hydra starts with "h").

Friends, fear not: the necromancy that brings old minds to new light is our sacred occupation, and those who wander the great halls of learning are shepherded to libraries. So, heroes, now that we are kitted up, let's head out; gird yourselves, prepare for encounter.

\section{MOVE 3: NORMALIZING THE STRANGE}

Not too far along, down from the door where we began, we discover a strange, new world ... and the first aspect of gameful design to which I'd like to draw your attention is structure-a basic course architecture. Second, we'll pay attention to story-an imaginative world you'll invite students to inhabit. And third, we'll consider aesthetics-imagery that fosters vibrancy and play. To illustrate these design concepts, I'll use a course I teach for our Graduate School of 
Theology entitled Introduction to Biblical and Theological Research. Here's the course description:

IBTR empowers students by establishing a foundation for information literacy and biblical interpretation. Our semester's journey takes us into an unexpected, "special world" of biblical studies: following the course of the Hero's Journey, students progress through four learning modules that hone skills for critical thinking, reflective reading, skillful research, and the artful use of information, crucial competencies that empower success as students progress to completion of their graduate degree.

This course, IBTR, has two iterations-an eight-week fully online version and a full-semester, hybrid version that functions more like a "flipped classroom" in which face-to-face meetings offer a workshop for deepening understanding of the content students have engaged outside of class. Let me describe how IBTR incorporates gameful design.

First, we think about structure. While the course meets week-toweek and moves linearly from task to task, module to module, activities and the course itself are suffused by the overarching model of Joseph Campbell's "Hero's Journey." His book The Hero with a Thousand Faces establishes a template of elements commonly found in epic story. Campbell's model describes a cycle that progresses through the following steps: leaving the familiar or "status quo," departing into the unfamiliar, encountering various trials and possibly death, coming away from trials with treasure or "boon," and returning home to share boon and discoveries. Now, I confess that, rather than taking students to the primary text, I introduce them to Campbell via a clever TedEd video that summarizes the Hero's Journey and stirs imagination through provocative visuals.

Departure, initiation, return-that's the Hero's Journey in a nutshell, and it happens to be the spiraling cycle of experience that I've encountered in students who are just beginning graduate biblical studies. Especially for students who uncritically hold assumptions or strong convictions about the infallibility of their sacred text, graduate studies can present a jarring new landscape. Employing the Hero's Journey model naturalizes our move into and through a "special world," in which biblical texts become unfamiliar as we encounter diverse interpretive methods and unexpected readings of scripture. Indeed, as students experience the Hero's Journey, they come to anticipate that texts will be unfamiliar and that new insight, like treasure, awaits discovery. 
The Hero's Journey model helps us normalize the strange. Experiences in the special world of our journey can feel like a gut-punch challenge to assumptions about the Bible but, as we return to the model again and again throughout the course, students are asked to reflect on where they are and how they are feeling at various moments in our journey, engendering pastoral care as needed as we travel the special world together. Courage, God mend all!

So, including a basic game architecture-what I'm calling structure and flow_-can be a significant aspect of gameful course design, in this case accomplished by incorporating a model that helps students conceptualize their journey through the course and beyond.

Second, let's think about story. Humans are storied creatures who inhabit storied worlds. The term student signifies a character in a drama; why not build out the stage upon which they'll play? The imagined world of story is formative space, and what we learn in storied worlds follows us out. So, another important aspect of gameful design is developing a storied world for students to inhabit as they progress through the course.

In the case of IBTR, here is our game in three moves: Move 1-You are a hero named Krino; Move 2-Following the hours of the Hero's Journey, make your way through an information dojo, honing skills for critical thinking (slicing skills for getting at what's behind encountered texts), reflective reading (sharpening sense-making tools for interpreting texts), skillful research (investigative skills for locating needed information), and artful application (using honed skills to demonstrate heroic formation); and finally, Move 3-Undertake the dojo master's final challenge to earn Krino's badge!

Though students are not initially aware, krino is a form of the Greek root from which we get our term "critical thinking.” Students are invited to inhabit the character Krino-to don the hero's garb, strap on the hero's katana, and to see themselves as a character in a story as much as they are a student in a class. Our self-introductions include posting an avatar-an image that captures how we envision ourselves as Krino. Remarkably, framing the course with story does not require me to drastically revise or re-tool tasks and assignments so that everything is about this hero named Krino; rather, all learning takes place within the overarching narrative, and Krino becomes a touchstone throughout our time together, simply recalling students to the game we're playing without the game becoming a distraction. So, another important aspect of gameful design is crafting an over- 
arching story for students to inhabit and characters with whom they can identify as they journey through the course.

Third, let's think about aesthetics, which is, in my opinion, an easy and compelling means for bringing game design to learning. Syllabus design itself invites play; perhaps more importantly, your learning management system can be embedded with imagery that resonates with and reminds students of the game they are playing. At my institution, we use Blackboard as our LMS, and GIFs or images can be embedded in tasks, announcements, and discussions. For IBTR, I created a "hero's hangout"-a discussion forum re-tooled as a space where students encounter content beyond what's been assigned; a space where they can meet, learn, ask questions, and discuss. And just as Mario munches mushrooms or Link rejuvenates with heart pieces, students in this game can earn Krino's Token of Healing by going above and beyond the minimum discussion requirementsKrino's token of healing allows them to obliterate a missed discussion post or shore up some extra points on an assignment. So, making good use of your LMS and syllabus by generating an aesthetic consistent with the storied world you've crafted is another way to incorporate gameful design in your course.

At the beginning of this presentation, instead of merely welcoming you to the Quill and Arrow with words, you found yourself visually dropped into a tavern space-perhaps as familiar as the Inn of the Prancing Pony-and it's remarkable to me that 30 seconds in a fictive, digital tavern compellingly pulls us into the story world of the game we're now playing. Luckily for us all, no sinister elves were lurking in our tavern waiting to lighten our purses (you may not think of elves as monsters, but just roll with me, it's incredibly difficult to find a familiar monster name that begins with the letter "e").

\section{MOVE 4: DOJO OF STRANGE EFFECTS}

\section{(SHARPENING COMPETENCIES)}

Our road goes ever on and on, and now we visit a dojo of strange effects. We're calling this stop on our journey a "dojo of strange effects" because it's off the well-worn and familiar paths. We visit this dojo with intention to sharpen a particular skill-to learn a special, new technique. Previously, I described gameful design in a for-credit course, where librarians-as-teachers lurk in classroom spaces. But much of our instructional work happens outside class- 
rooms in co-curricular spaces, and so I'd like to illustrate gameful design for library-ronin-the wandering librarian without a classroom-home. (Ronin is not a monster name; it's a term that refers to a samurai without a lord or master. But keep your ears sharp, heroesmonsters lurk! Also, if you are able, please forgive what must seem like blatant cultural appropriation; the world of gaming and gamers brims with oblivious Japan-ophiles).

Our dojo of strange effects is a space for sharpening info skills and for mastering research competencies outside the classroom, in the co-curricular regions where librarians-as-teachers live, move, and have our being. To illustrate co-curricular gameful design, let me describe a gamified learning module we developed last year to sharpen specific skills and competencies.

In Summer 2019, we were approached by our Freshman Experience team, who requested a Blackboard module to introduce new students to certain library services and initiate reflection about college-level research. We believed a gamified approach would enhance delivery, experience, and learning assessment; so, we decided upon an escape-room theme to provide the concept, atmosphere, and architecture necessary for an enjoyable and instructive experience.

Students were dropped into the story by viewing the introductory video. There, they learned that an over-zealous campus patroller named Cam Raman had discovered them in the library after hours-and worse, Cam Raman had captured their friend, shuffled her back to the dorms, and confiscated her cell phone. But Cam Raman likes games, so he offers a sporting chance; to escape the library and retrieve their friend's phone, they have to play the game and progress through challenge "rooms" to discover "keys"-words that become the terms of their escape.

So, let's pause to recall our three aspects of gameful design: structure (or, basic architecture), story, and aesthetic. In this case, the basic architecture involves "rooms" through which students progress to the end of the game; as for the story, students find themselves trapped in a virtual library, and progression through each learning area invites discovery as students search "rooms" for "keys"; and the aesthetic relates to this maniacal Cam Raman who toys with trapped students and willy-nilly snatches their cell phones.

Using instructional videos we had previously developed, we articulated learning outcomes related to specific competencies. Students 
began in Blackboard. After accessing the module, they watched the initial video and were dropped into the story. Then they entered the first room, the dungeon, to discover the first key. After watching a brief video introducing the library homepage and discovery tool, students essentially moved through a series of linked Google Docs with Undertale-themed GIFs to create a sense of game-like movement and dynamism. The dungeon measured student comprehension of content from the Homepage video, and successful navigation of the dungeon resulted in discovery of the first key.

In the second room, students sharpened skills for critical questioning. After watching the video, they engaged a flipbook-themed task related to questioning - thinking about who, what, how, and why questions. Eventually, they discovered the second key at the end of the flipbook. Then, students entered the third room-an introduction to plagiarism with a task that revealed the final key. With all the keys in hand, students moved to the final room - the boss battle.

The final room consisted of learning assessment as well as a fillin-the-blank style question in which students submitted the discovered keys (thereby “unlocking the door" for escape!). Up to this point, discovery of keys signified that students successfully moved through each room. In the final room-a simple test developed in Blackboard-students were prompted to respond to questions mapped to outcomes and then to submit the "keys." Successful completion of the final room opened the door for escape! Time-on-task for the entire module was about 45 minutes. Following completion of the test (i.e., once the student escaped), a prompt encouraged students to visit the library front desk to fulfill the overarching story (you may remember) by retrieving their friend's captured phone. Students who visited the front desk to claim the completion card were also given candy as a bonus treat.

In the end, Freshman Experience decided they didn't want to include library information after all, so we piloted our escape-avirtual-library module as part of library instruction in a Freshman Composition class. Future iterations must better consider accessibility; in this first attempt, we were primarily after proof of concept. I envision developing a small battery of gamified modules like this for deployment in both curricular and co-curricular instruction. In true gamified fashion, successful completion of these modules will earn students a digital badge, although we currently have no Universitywide infrastructure to recognize co-curricular achievement, which 
is, dear friends, another problem for another presentation at another time. No need now to chase that rabbit trail-a trail that ends not with a furry friend but at the mouth of the terrible cave where the vicious Killer Rabbit of Caerbannog waits-yes, you heard it, another monster named, and that monster is rabbit ("rabbit" begins with "r").

\section{MOVE 5: ENCOUNTER AS BOON}

So now, friends, adventurers, we come full circle and return to the Quill and Arrow, having moved through the forever-cycle of the Hero's Journey, like the ouroboros who perpetually eats its own tail (our final monster! Ouroboros begins with "o," by the way). And this brings us to the end of our quest, the game we've been playing today. You've done it! You've discovered the keyword-adventurers, you are all true heroes and, if we were in person and this wasn't a digital tavern, well, I'd buy you all a round to celebrate the end of our hero's journey together!

By incorporating gameful design, we are intentionally bringing learning to spaces of desire, not least because humans are, after all, players - creatures-at-play-and all human activity is (or at least should be) infused with play (cf. Huizinga 2014). Gameful design in research instruction and theological education opens new horizons for actualizing (in)formation as we librarians-as-teachers inhabit liminal spaces between curricular and co-curricular contexts, harbinging encounter in strange, special worlds, forming and informing those we serve, crafting whole-person learning of blood and bone, virtue and vengeance.

\section{SELECT RESOURCES}

Bell, Kevin. 2018. "Gameful Design: A Potential Game Changer.” Educause Review (May/June): 41-8.

Boskic, Natasha and Sharon Hu. 2015. "Gamification in Higher Education: How we Changed Roles." Proceedings of The European Conference On Games Based Learning, 1741-8.

Campbell, Joseph. 2008. The Hero with a Thousand Faces. Novato, CA: New World Library.

Cheong, Christopher, Justin Filippou, and France Cheong. 2014. "Towards the Gamification of Learning: Investigating Student 
Perceptions of Game Elements." Journal of Information Systems Education, 25, no. 3: 233-44.

Cohen, Aaron M. 2011. “The Gamification of Education.” Futurist 45, no. 5: 16.

Dichev, Christo and Darina Dicheva. 2017. "Gamifying Education: What Is Known, What Is Believed and What Remains Uncertain: A Critical Review." International Journal of Educational Technology in Higher Education 14, no. 1: 1-36.

Huizinga, Johan. 2014. Homo Ludens: A Study of the Play-element in Culture. Boston: Beacon.

Kapp, Karl M. 2012. The Gamification of Learning and Instruction: Game-based Methods and Strategies for Training and Education. San Francisco, CA: Pfeiffer.

McGonigal, Jane. 2011. Reality Is Broken: Why Games Make Us Better and How They Can Change the World. New York: Penguin Press. 